\title{
The relationship between labour social responsibility practices and reputation
}

\begin{abstract}
Purpose - The main purpose of this paper is to analyse whether Labour Social Responsibility (LSR) practices influence on Corporate Reputation (CR) and on Labour Reputation (LR).
\end{abstract}

Design/methodology/approach - LSR is defined as all those labour practices made by a company for the benefit of employees voluntarily and not imposed by labour legislation. An index developed by content analysis was created to measure LRS. CR and LR scores were obtained from the Business Monitor of Corporate Reputation (MERCO) for the period of 20062010. Furthermore, based on the previous literature, the study considers other generic variables that influence the process of creating reputation, such as visibility and environmental impact, as well as intrinsic characteristics of each company (size, financial performance and debt). The model was estimated by the Generalized Method of Moments (GMM) on a data panel for the 100 most reputable firms in Spain in each year during the period 2006-2010.

Findings - The results obtained show that LSR carried out by the company has a direct and positive relationship with the reputation. Thus, corporate and labour reputation and their evolution depend on ability of the LSR strategy of the company to satisfy to future expectations of stakeholders.

Originality/value - Previous literature considered the impact of different dimensions of Corporate Social Responsibility on CR, e.g., environmental, communication, quality of products, but did not consider labour practices.

Keywords: Labour Social Responsibility, Corporate Reputation, Labour Reputation, Generalized Method of Moments

Paper type: Research paper

\section{Introduction}

Corporate social responsibility (CSR) is becoming increasingly important in business because investment in responsible practices has become a sign of differentiation in the market and a source of competitive advantages (Vilanova et al., 2009). This has contributed to the increasing number of companies that consider CSR in their strategies and actions (European Commission, 2001; Lichtenstein et al., 2004; Luo and Bhattacharya, 2006). Consistent with this, CSR has been a relevant concept for research in the scientific field, focusing on the study of its definition, measurement and effects on firm performance. 
There has been a proliferation of studies about the impact of CSR on the company's image (Endacott, 2004; Ellen et al., 2006), consumer perceptions of product quality (Becker-Olsen et al., 2006), company ownership characteristics (Fombrun and Shanley, 1990), access to capital (Cochran and Wood, 1984; Hart, 1995), and financial performance (FP) (Griffin and Mahon, 1997; Waddock and Graves, 1997; Luo and Bhattacharya, 2006; Fernández and Luna, 2007). The relationship between CSR and FP is one of the most widespread in academic literature and, more specifically, the incidence of some of the dimensions of CSR on the FP, such as society (Lev et al., 2010), environment (Murray et al., 2006), products (Kim et al., 2001), communication (Watson et al., 2002) or governance / management (Coffey and Fryxell, 1991).

Another line of study dealt with quite often was the relationship between CSR and reputation. This relationship has been looked at both for CSR as a whole (Cochran and Wood, 1984; Fombrun and Shanley, 1990; Brammer and Pavelin, 2006) and for specific external dimensions of CSR (concerned with clients, suppliers, consumers, community and environment). However, there is a gap in the strategic management literature about the study of the possible link between the internal dimension of CSR regarding employees and reputation. The impact of corporate social responsibility practices for employees on reputation is still unknown, and even more so about the impact on firm's reputation in the labour market (hereafter labour reputation).

The dimension of the CSR which includes the social responsibility practices for employees is called in this study Labour Social Responsibility (LSR). LSR implies social responsibility practices developed by the company to improve working conditions. The origin of this desire for the improvement of the working class, in order to contribute to the goal of greater social equality (Blanco, 2004), became apparent at the beginning of the twentieth century with the unionisation of workers. Workers joined labour unions as a way to increase their stake in the power struggle of interests in businesses. As a result of such social movements, labour actions and their impact on the company are considered to be an area of interest in social research (Fenwick and Bierema, 2008).

The study of possible links between the LSR and corporate reputation (CR), and in particular between the LSR and the labour reputation (LR) is a novel contribution to the strategic management literature and, particularly, to those research lines that address the links between CSR and reputation, and creating or enhancing of reputation through the CSR. The purpose of this paper is to determine whether the practices of LSR influence the creation of CR and LR in companies. To carry out the empirical model, two of the reputational rankings published by the Business Monitor of Corporate Reputation (MERCO) for Spanish companies are used. On one hand, the model uses 100 companies with the highest CR and, on the other hand, it uses 100 
companies with the highest LR or "Best Workplaces". The results of these rankings were collected each year during the period of 2006-2010.

\section{The theoretical framework}

Reputation acts as a driver to implement CSR (Maron, 2006; Vilanova et al., 2009), since CSR has its effect on the creation of reputation through the legitimation of their activities by stakeholders (de Quevedo-Puente et al., 2007; Reverte, 2009). The concept of CSR is defined as "the voluntary commitment of companies with the development of society and the preservation of the environment, from its social commitment and responsible behaviour towards companies and social groups with whom they interact" (Lizcano and Moneva, 2003). CRS has been considered by the academic literature as a multidimensional construct, as it affects a variety of stakeholders. The European Commission (2001) in its statement "Green Paper: Promoting a European framework for corporate social responsibility" has established an internal dimension and an external dimension of CSR. In the internal dimension, responsible management of human resources, safety and health of its employees, managing change, and management of natural resources used in production are included. In the external dimension, practices considered relevant to customers, suppliers, consumers, public authorities, NGOs, community and the environment are included.

The impact of CSR on the reputation has been studied in the academic literature (Brammer and Pavelin, 2006; de Quevedo-Puente et al., 2007; Vitezić, 2011; Moura-Leite and Padgett, 2014) and also the impact of certain dimensions of CSR on CR, such as products (Shapiro, 1983; Padgett and Moura-Leite, 2012), communication (Kim, 2007; Reese and Westphal, 2004) or environment (Buysse and Verbeke, 2003). However, a gap has been found in the study of the internal field of CSR practices concerning to human capital, i.e. LSR.

In this study, LSR is defined as all those labour practices voluntarily made by the company, i.e., those labour practices that are not imposed by labour laws. In the workplace we should differentiate between the practices made by the company for the compliance with labour laws from those practices that qualify the company as socially responsible. In order to attract skilled workers and increase their continuance in the company, the European Commission (2001) suggested the following LSR practices: training (lifelong learning), delegation (workers take more responsibility), transparency (increase the access to information about the company), reconciling family and professional life (balancing work, family and leisure), equal opportunities (greater diversity of human resources, equal pay and career prospects for women), participation (participation in profits or shares of the company), outplacement service (considering the employability) and safety in the workplace. 
Social actions by the company emerge to legitimatise its activity with stakeholders and contribute to social well-being beyond the economic interests of the company. The legitimation process begins with an assessment of the stakeholders of CSR actions over time, resulting in the consolidation of firm's reputation. Reputation is built through the information (e.g., strategic, financial and governance) that is generated over time according to the observed behaviour of the agent when facing different aspects (Martínez and Olmedo, 2010).

In the creation of reputation, the assessments made by stakeholders are based on the past actions of the firm and on the future expectations about the company (see Figure 1) and, therefore, there is a dynamic component in the development of reputation (Mahon, 2002; Martínez and Olmedo, 2010). As a consequence of this building process, the reputation has some specific features.

1. Reputation is an intangible asset and its value has a dynamic behaviour throughout time. (Carmichael, 1984; de Quevedo-Puente et al., 2007)

2. It is important to take into account that for the creation of reputation extended periods of time are necessary (Shapiro, 1983; Dierickx and Cool, 1989; Hall, 1992), which makes this asset inimitable in the short term for competitors (Dierickx and Cool, 1989; Hall, 1992).

3. The value of reputation is accumulated in a particular organization and it is nontradeable (Dierickx and Cool, 1989; Schnietz and Epstein, 2005; Vilanova et al., 2009).

\section{FIGURE 1 - Dynamism of building reputation}

Although the building of CR and LR are based on the stakeholders' assessment about the behaviour of the firm, they do not assess exactly the same issues for both reputations. Fombrun (1996) defines corporate reputation as follows: "It is a perceptual representation of a company's past actions and future prospect that describe the firm's overall appeal to all of its key constituents when compared with other leading rivals". So, in the case of CR all business areas are considered or evaluated, but LR is merely the result of the evaluation by the stakeholders of the actions concerning to the working environment.

As a result of the stakeholders' assessment about the company's behaviour, reputation becomes a public sign of the quality of products, jobs, strategies and prospects compared to their competitors (Wilson, 1985). Particularly, a positive reputation in labour market is a source of information that reduces the cost of the firm to search for staff, the cost of training and the costs associated with labour turnover (Chauvin and Guthrie, 1994), it increases the motivation and the attraction of good employees (Roberts and Dowling, 2002), and some authors claim that a positive reputation in the labour market generates value for the company (Chauvin and Guthrie, 1994), as well as an advantage in the efficiency of human resources (Fombrun, 1996). 
According to the multiple competitive advantages gained by the company through reputation previously cited in academic literature, the improvement in their reputation will be positive for firms.

The present paper would be of interest for academics and practitioners to know if the development and inclusion of LSR practices into the human resource strategies could be used also with the objective to contribute to the creation of reputation. Investment in CSR has been justified as a tool to use as a competitive strategy of the company (Porter and Kramer, 2002; Saiia et al., 2003) and for its positive impact on reputation (Brammer and Pavelin, 2006). Just as previous studies confirmed the positive effect of other dimensions of CSR on CR, we expect that LSR increases CR. With this aim, the following hypothesis is proposed to be tested:

Hypothesis 1. (H1). The labour social responsibility strategy has a direct and positive relationship with corporate reputation.

Furthermore, considering that LSR practices aim to improve the working conditions of employees and that those practices are evaluated by stakeholders for the creating LR, we would like to test the relationship between these two magnitudes:

Hypothesis 2. (H2). The labour social responsibility strategy has a direct and positive relationship with labour reputation.

\section{Methodology and data}

Sample

In order to test the hypotheses proposed, we use two equations. One of them to contrast the Hypothesis 1, where the dependent variable is $\mathrm{CR}$, and the second equation to contrast the Hypothesis 2, in which the dependent variable is LR. As a result, in this study there are two samples. The list of over the 100 companies with higher CR in Spain sing up the first sample, and the list of the 100 companies with higher LR comprises the second one. Both lists were collected each year during the period of 2006 to 2010 from the Business Monitor of Corporate Reputation (MERCO), which has been a reference of the firm's reputation in Spain since 2001. MERCO offers two types of rankings "Merco Companies" and "Merco People" composed of 100 firms each. In this paper CR will be measured with the firm's score on the ranking "Merco Companies", and LR will be measured through "Merco People". The sample regarding to CR has 477 observations, conforming a panel data for 5 years. The other panel data has 461 observations concerning to LR for the same years. Neither of the two have reached 500 observations (observations per year $(n)=100$, number of years $(T)=5$ ) because it was not possible to obtain the full financial information of some firms included in the rankings. 


\section{Dependent variables}

Corporate Reputation - The evaluation process to create the ranking "Merco Companies" follows several consecutive steps. A first provisional ranking is created by Spanish managers, which belong to management committees of all the companies that have an annual turnover in Spain of more than 50 million Euros. The survey asks the managers to evaluate the different companies according to six first-level variables (economic-financial results, quality of the product-service, corporate culture and labour and ethical quality, corporate social responsibility, overall size and international presence, and innovation). Subsequently, each company included in the provisional ranking is evaluated directly by different groups: financial analysts, consumer groups, NGOs, trade unions and opinion leaders. A third evaluation is preformed called "Tracking Merco", which is based on results extracted from the perspectives of final consumers and likewise with the results of the partial ranking "Merco People" that are incorporated. Finally, the merits earned by companies are verified and valued from 0 to 10,000 points. So the list of 100 Spanish companies with the greatest corporate reputation is obtained, and also an exact score for each of them as well, which makes it possible to develop a ranking.

Labour Reputation - The reputation index "Merco People" refers to a ranking of the most reputable companies to work for. The evaluation methodology of this index integrates six different assessments. Last year university students, alumni of business schools and human resource managers are surveyed to identify the most desirable companies to work for in Spain. Subsequently, a benchmarking about human resource management policies is made among the 100 companies of the highest corporate reputation, and then reputation surveys are conducted internally among the employees of those 100 companies. Finally, an online opinion survey is available for anyone wishing to respond through the website of Merco.

\section{Independent variable}

Labour Social Responsibility (LSR) - To measure the explanatory variable LSR, our own index has been created through content analysis, which is a very common technique of this field (Graves and Waddock, 1994; Branco and Rodrigues, 2008). The construction of the LSR index is due to the absence of a previously developed index for the companies considered in this article.

The indicator LSR considers the areas of interest identified in the labour sphere of the European framework for corporate social responsibility (European Commission, 2001), and the items to measure these areas are based on the most common labour items used by institutions (Global Reporting Initiative (GRI), Jantzi Research, Orservatory of CSR, etc.) and other recent studies (Moore, 2001; Domench, 2003; Aksu and Kosedag, 2006; Fernández and Luna, 2007; Lindgreen et al., 2009). Table 1 shows the items selected classified according to the areas 
mentioned by the European commission. These items were subjected to an analysis of reliability and validity using Cronbach's alpha, obtaining a result of $\alpha=0.89$.

This index quantifies responsible actions in the workplace for each company using the following analysis: If a company performs labour actions which are considered by the items in Table 1, we would give this item a value of 1 , otherwise we would give this item a value of 0 . Finally, we add up all the items $(n 1+n 2+\ldots \ldots+n j)$ and it is divided by the total $(\mathrm{N})$, and as a result we obtain a score of LSR between 0 and 1 .

The information required to develop this index was obtained from the social information reported annually by each company on its website or in their corporate sustainability, social responsibility and/or corporate citizenships reports during the period of 2006 - 2010, due to it being accessible information for all stakeholders. In order to make the process of collecting data as accurate and objective as possible, labour guidelines by the GRI for the development of CSR reports were consulted.

TABLE 1 - Labour Social Responsibility actions considered for the construction of the LSR index

\section{Control variables}

In addition, based on the previous literature, the effect of control variables should be isolated in the process of building reputation. This study considers generic variables such as visibility and environmental impact, as well as several intrinsic characteristics of each company (size, financial performance and debt) as control variables. Theoretical justification and measurement of the control variables of the model is described below.

Several reasons justify the importance of considering the firm's size for this research. Large firms have a higher social and economic impact than smaller ones, due to a larger market share and the large number of relationships with stakeholders, which will result in an increased demand for information from these companies (Sotorrío and Diez, 2011; Brammer and Pavelin, 2004). In this context, big companies tend to be subject to public scrutiny, so there is a wealth of information about them. This availability of information can benefit large companies in the creation of reputation, due to the increase familiarity between stakeholders and company activities (Fombrun and Shanley, 1990), and it may bias the assessments of reputation (Brammer and Pavelin, 2006). In this paper, firm's size is measured by the value of total assets (Mahoney and Roberts, 2007; Griffin and Mahon, 1997; Waddock and Graves, 1997; Brammer and Millington, 2006).

Just as with the size of the firm, financial results of the company also will be significant for building reputation. Brammer and Pavelin (2006) stated that a high FP serves as an indicator of 
good company management and the appropriate allocation of resources. The most profitable companies in the market will be better valued by stakeholders, especially those with a financial halo (shareholders, lenders and financial analysts), helping to create or maintain a good reputation in the market. Furthermore, it is considered that companies with higher financial performance have more resources to implement socially responsible actions (Roberts, 1992; Preston and O'Bannon, 1997; Griffin and Mahon, 1997; Moore, 2001) to create reputation. Following that reasoning, debt is a variable of interest in this analysis because capital being less available could lead to less investment in social actions (Brammer and Pavelin, 2006), and finally it would impact on reputation, thereby establishing a negative relationship between debt level and reputation. In this study return on assets (ROA) is used as a proxy variable for financial performance, because it is considered the most commonly used rate of return on investment, and the ratio used to measure the level of debt of a company is the total long-term debt divided by total assets (Waddock and Graves, 1997; Mahoney and Roberts, 2007). The accounting data necessary for the above variables (size, profitability and debt) for each company were collected from the Amadeus, SABI and Bankscope databases.

Furthermore, it is important to control generic features of the firm depending of the sector of activity, since they can affect reputation. The visibility of the company depends on the proximity of the consumer to the company (Branco and Rodrigues, 2008), the amount of information provided to its stakeholders (Theriou and Chatzoglou, 2009), and the presence of the company in the media. The knowledge that society has of its business activity and the proximity of the consumers to the company, have a significant direct relationship with company reputation (Cottrill, 1990). The proximity of the end consumer to the sector is considered a proxy variable for visibility. In this study, a binary measure has been used to distinguish between high-visibility (close to the consumer, and whose names are expected to be known by most members of the general public) and low-visibility companies. The authors (Brammer and Pavelin, 2006; Branco and Rodrigues, 2008) identified the following business activities with high visibility: consumer services, consumer goods (home appliance, textiles and clothing, food and beverages), pharmaceutical, telecommunications, electricity, gas distribution, water distribution and financial service. The above activities are given the value of 1 in the database and the rest of activities will receive a value of 0 .

The society's growing concern for the preservation of the environment has meant that environmental issues become relevant for corporate governance (Toledano and Gessa, 2009). Nowadays, the environmental performance of companies is judged by society, since the stakeholders demand environmental responsibility. There are companies with a higher exposure to the scrutiny of the stakeholders, especially those in the industrial sector, which has withstood the highest pressure due to the environmental deterioration. Therefore, the environmental 
impact is included in the study as one of the variables that potentially influences corporate reputation and labour reputation, although it depends on the sector or the business activity. Industries that have a large impact on the environment are considered as those that have greater exposure to public scrutiny because their activities involve a greater risk of environmental impact (for natural resource depletion or pollution). The previous literature (Hoffman, 1999; Bowen, 2000; Branco and Rodrigues, 2008) identified the greatest impact activities, which are: mining, oil and gas, chemicals, construction and building materials, forestry and paper, steel and other metals, electricity, gas and water distribution. All others activities are considered less harmful. This variable is thus defined as a dichotomous variable, so that it is considered with value 1 those activities of greatest environmental impact, and 0 the rest.

\section{Data analysis method}

Reputation is a stock variable (de Quevedo-Puente et al., 2007) with an autoregressive character, as the current reputation is partly composed of the reputation gained in past periods. Pooled estimates would not be consistent due to the correlation between the regressors and the error term (Baltagi, 2008). For this reason, the empirical analysis to contrast the hypotheses is performed with panel data analysis, using a dynamic model that includes a lagged dependent variable. The Generalized Method of Moments (GMM) allows to control the individual unobservable heterogeneity between different companies and to eliminate the risk of obtaining biased results. Particularly, in this study the system GMM estimator is used, which is the most appropriate method for estimating a panel with the lagged dependent variable. The system GMM estimator provides a consistent estimator that increases the level of efficiency while maximizing the information incorporating a greater number of instruments (Arellano and Bond, 1991). This method of estimation is indicated for the use of micro panels, which is very common in the study of social sciences (Baltagi, 2008).

The following equations examine the impact of LSR on CR (Equation 1) and LR (Equation 2):

$$
\begin{aligned}
& C R_{i t}=\alpha_{0}+\alpha_{1} C R_{i, t-1}+\alpha_{2} L S R_{i t}+\alpha_{3} S I Z E_{i t}+\alpha_{4} F P_{i t}+\alpha_{5} D E B T_{i t}+\alpha_{6} V I S I B_{i t}+\alpha_{7} E N V I_{i t}+\sum_{t=2006}^{2010} Y_{t}+\gamma_{i}+\mu_{i t} \\
& L R_{i t}=\beta_{0}+\beta_{1} L R_{i, t-1}+\beta_{2} L S R_{i t}+\beta_{3} S I Z E_{i t}+\beta_{4} F P_{i t}+\beta_{5} D E B T_{i t}+\beta_{6} V I S I B_{i t}+\beta_{7} E N V I_{i t}+\sum_{t=2006}^{2010} Y_{t}+\gamma_{i}+\mu_{i t}
\end{aligned}
$$

In Equation 1 above $C R_{i t}$ is the corporate reputation, which is the dependent variable, and $C R_{i, t-1}$ is its lagged value introducing dynamicity into the model. $L S R_{i t}$ is the labour social responsibility strategy of the firm $i$ in year $t, V I S I B_{i t}$ is the visibility of the company $i$ in year $t$, $E N V I_{i t}$ is the environmental impact of the company $i$ in year $t, S I Z E_{i t}$ is the size of the company $i$ in year $t, F P_{i t}$ is the financial performance of the company $i$ in year $t, D E B T_{i t}$ is the indebtedness 
of the company $i$ in year $t, \sum_{t=2006}^{2010} Y_{t}$ is a set of time dummy variables that collect temporary effect, $\gamma_{i}$ is the unobservable heterogeneity which is assumed constant for the company along $t$, and $\mu_{i t}$ is the error term. In Equation 2 above $L R_{i t}$ is the labour reputation of the company $i$ in the year $t$, and $L R_{i, t-1}$ is the endogenous variable lagged one period. The rest of the variables represent the same as in the Equation 1. In this paper the lagged corporate reputation (CRt-1) and the lagged labour reputation (LRt-1) are considered as predetermined variables. Labour social responsibility (LSR), size, financial performance and indebtedness are considered endogenous variables, and the rest of variables are considered exogenous variables. The results were obtained through the software STATA 11.

\section{Results}

In this section, firstly, the samples used in this study are described using the main descriptive statistics (mean, standard deviation, maximum, minimum) (Table 2) and the Pearson's correlation coefficients of the variables used in the model (Table 3). Secondly, the model validation and interpretation of the results are presented.

Corporate reputation reaches an average score of 3,653.12 points and the labour reputation $3,488.81$ points. The LSR index takes an average value of 0.37 . The means of dichotomous variables (visibility and environmental impact) are useful in order to know the positioning of the companies in the sample. In this case, $64 \%$ for the CR sample and $59 \%$ for the LR sample of the companies have a high visibility. $23 \%$ and $24 \%$ of the firms for CR and LR samples, respectively, belong to sectors with high environmental impact. The LSR has a positive and significant correlation with corporate reputation $(0.287, \mathrm{p}<0.001)$ and labour reputation $(0.189$, $\mathrm{p}<0.001)$.

\section{TABLE 2 - Descriptive statistics}

\section{TABLE 3 - Pearson Correlation matrix}

\section{TABLE 4 - System GMM Estimates of corporate reputation and labour reputation.}

Table 4 shows the estimation results of the models proposed to evaluate the influence of the LSR practices on the creation of CR and LR. The correct use of the system GMM estimator has been proven by the specification test. The test of first-order autocorrelation, M1, with a p-value under 0.05 indicates the existence of dynamic effects (Arellano and Bond, 1991). Also, the M2 statistic confirm there is not a second-order autocorrelation with a p-value higher than 0.05 . The Hansen test corroborates there are not over-identified equations (p-value>0.05), and the Wald tests with p-values $<0.05$ test the joint significance of the explanatory variables (z1) and time dummies (z2). After verifying the correct use of the estimation method proposed for this study, the results are analyzed below. The results of the estimation of this model have been obtained 
from typified variables, hence the coefficients of the variables in Table 4 are standardized coefficients $(\beta)$, which allow to determine what explanatory variable has greater weight to explain the dependent variable.

According to the results, companies that carry out labour social practices will obtain a higher reputation. The coefficient of LSR obtained in the estimation of the Equation 1 supports $H 1$, due to a positive relationship between the LSR and CR for a significance level at $99 \%$. In the estimation of the Equation $2 \mathrm{LR}$ is the dependent variable to contrast the $H 2$. The variables LSR and LR maintain a positive relationship for a significance level at $99 \%$, thus supporting $H 2$. Greater investment in LSR practices would be rewarded by stakeholders with greater labour reputation for the firm.

The dynamic system GMM estimator provides information about the lagged dependent variable. In the case of $C R_{t-1}$, it has a positive and significant relationship with $C R_{t}$ at a $99 \%$ level of significance. Also, a positive link between $L R_{t-1}$ and $L R_{t}$ in Equation 2 has been confirmed, at a level of significance of 99\%. Therefore, the reputation of the company (corporate and labour) in year $t$ is highly dependent on the reputation of the company in year $t-1$.

Regarding the influence of the control variables on corporate and labour reputation, all the expected relationships according to academic literature were supported with the exception of the variable "financial performance". The results confirm that size and visibility of the company have a positive effect on the creation of corporate reputation and labour reputation. On the other hand, debt and environmental impact of the company denote a negative effect on both reputations. The expected effect of the variable financial performance on reputation was not significant in any of the two samples analysed.

\section{Discussion}

A company's reputation is a sign of differentiation in the market and source of competitive advantage (Vilanova et al., 2009). Therefore, the study of the creation of reputation has been a topic of interest in the academic literature. The definition of reputation proposed by Fombrun (1996) is one of the most cited in the literature, which says that reputation is formed from the assessment of stakeholders on the firm's performance. Thus, the social performance of a company implies the starting point for building a reputation. Following this line of thought, there are multiple studies that have tested the relationship between CSR and CR, and the relationship between some dimensions of CSR and CR. However, the labor dimension of CSR has not received the same attention. Consequently, this paper has investigated the influence of LSR on CR and on LR. LSR is part of the internal dimension of CSR and the study of its relationship with the reputation covers a gap in the research line of the creation of reputation. 
The results obtained for the two hypotheses tested reinforce the positive heuristic paradigm that link CSR and reputation (Brammer and Pavelin, 2006; Alvarado and Schlesinger, 2008; MouraLeite and Padgett, 2014). The findings confirm the relationship between LSR and CR / LR. Furthermore, the effect of the control variables on the reputation justified by the literature review was confirmed for most variables. The larger firms and those with greater visibility or proximity to the consumer get a higher CR and LR, while companies with a higher level of debt and those whose activity causes a greater impact on the environment suffer a negative impact on both reputations.

However, in this paper an exception has been found insofar as the result of the financial performance, since its positive effect on the CR and LR has not been confirmed. The lack of significance of the financial performance impact on CR and LR could be explained by several reasons. On the one hand, the Merco's indicators seem not to have as much financial halo as other indicators of reputation. This due to the fact that Merco's indicators are constructed based on the assessment of the firm actions by all stakeholders, while other rankings, as Fortune, are based on the evaluation of respondents with strong financial halo (CEOs, executives and financial analysts) (Baden-Fuller et al., 2000), which makes financial variables have a higher impact on reputation. On the other hand, European economies, especially the Spanish one, has been severely hit by a deep financial crisis. The financial results of the companies, as flow variable, have been more volatile than the reputation variable because, as a stock variable, its changes are visible on a longer period of time.

This approach from the labour dimension of CSR involves practical and theoretical implications. For researchers, this internal dimension of CSR is displayed as a wide field of research for the firm's strategic management. At the advantages mentioned by some authors about CSR labour practices, i.e. LSR (increased worker commitment, increased satisfaction, reduced absenteeism, reduced the cost of selection, etc (Osterman, 1995)) should be added the ability to generate $\mathrm{CR}$ and LR, and the competitive advantages derived from them. For practitioners, striving to create CR and LR can be the engine to boost the LSR practices, thus benefiting employees (getting better workplaces) and businesses (increasing its reputation and gaining competitive advantages).

\section{Conclusions}

The relationship between business and society has strengthened; largely by the amount of media available for the dissemination of information about CSR, among others. Social investment in CSR practices made by the company has been justified with getting extra business benefits derived from obtaining reputation, such as increased competitiveness, differentiation, better candidates for jobs, attracting investment, creating entry barriers, and reducing transaction costs, 
among others (European Commission, 2001). Reputation has become an important intangible asset for businesses since it is a non-marketable and inimitable assets signify differentiation in the market.

Using data of the Spanish firms with a higher CR and LR between the years from 2006 to 2010 according to Merco's rankings, the analysis of this study test whether LSR practices exert a positive influence on building corporate reputation and labour reputation (specifically). The shortage of contributions aimed at the study of LSR and its relation with reputation makes it necessary to present new contributions in this field of research.

The results of this paper confirm that LSR conducted by the company has a directly and positive influence in creating CR and LR. Considering this finding, the reputation will have several functions for stakeholders. Firstly, CR and LR work as a mechanism of control on LSR actions undertaken by companies. Secondly, both reputations act as a source of information in the market, indicating the degree of a firm's responsibility with society and agents with whom it interacts. Finally, in the observed relationship between the LSR and reputation, one of the most important contributions of this study is the importance acquired by labour practices as part of the social actions promoted by businesses. Human resource management should consider the stakeholders' expectations to create reputation, since the evolution of the reputation depends partially on the evolution of the LSR.

Several limitations of the study should be noted. The main limitation of this paper is the dependence of social responsibility reports for the construction of LSR indicator, due to the lack of an available standard measure of LSR practices. Furthermore, the labour environment has particular characteristics and conditions in different countries. For this reason, the conclusions of this study cannot be extrapolated directly to any other country. Consequently, one of the possible future areas of works in this line of research is the study of the relationship between LSR and reputation in other countries. Also, the study of the individual impact of the LSR practices on corporate and labour reputation in order to identify specific LSR strategies to increase their reputation might be interesting for practitioners. Finally, after confirming the importance of LSR in creating reputation, the analysis of the relationship between LSR and value creation is another issue to address in this line of research that would help improve the existing knowledge about human resources management.

\section{References}

Aksu, M. and Kosedag, A. (2006), "Transparency and disclosure scores and their determinants in the Istanbul Stock Exchange", Corporate Governance: An International Review, vol. 14, no. 4, pp. 277-296.

Alvarado Herrera, A. and Schlesinger Díaz, M.W. (2008), "Dimensionalidad de la responsabilidad social empresarial percibida y sus efectos sobre la imagen y la reputación: 
una aproximación desde el modelo de Carroll", Estudios Gerenciales, vol. 24, no. 108, pp. 37-59.

Arellano, M. and Bond, S. (1991), "Some tests of specification for panel data: Monte Carlo evidence and an application to employment equations", The review of economic studies, vol. 58, no. 2, pp. 277-297.

Baden-Fuller, C., Ravazzolo, F. and Schweizer, T. (2000), "Making and Measuring Reputations: The Research Ranking of European Business Schools", Long range planning, vol. 33, no. 5, pp. 621-650.

Baltagi, B. (2008), Econometric analysis of panel data, John Wiley \& Sons.

Becker-Olsen, K.L., Cudmore, B.A. and Hill, R.P. (2006), "The impact of perceived corporate social responsibility on consumer behavior", Journal of Business Research, vol. 59, no. 1, pp. 46.

Blanco Blanco, J. (2004), "El sindicalismo español frente a las nuevas estrategias empresariales de trabajo y empleo", Cuadernos de relaciones laborales, vol. 22, no. 2, pp. 93-115.

Bowen, F.E. (2000), "Environmental visibility: a trigger of green organizational response?", Business Strategy and the Environment, vol. 9, no. 2, pp. 92-107.

Brammer, S.J. and Pavelin, S. (2006), "Corporate reputation and social performance: The importance of fit", Journal of Management Studies, vol. 43, no. 3, pp. 435-455.

Brammer, S. and Pavelin, S. (2004), "Building a Good Reputation", European Management Journal, vol. 22, no. 6, pp. 704-713.

Brammer, S. and Millington, A. (2006), "Firm size, organizational visibility and corporate philanthropy: an empirical analysis", Business Ethics, vol. 15, no. 1, pp. 6.

Branco, M.C. and Rodrigues, L.L. (2008), "Factors influencing social responsibility disclosure by Portuguese companies", Journal of Business Ethics, vol. 83, no. 4, pp. 685-701.

Buysse, K. and Verbeke, A. (2003), "Proactive environmental strategies: a stakeholder management perspective", Strategic Management Journal, vol. 24, no. 5, pp. 453-470.

Carmichael, H.L., (1984), "Reputations in the Labor Market", The American Economic Review, 74(4), pp. 713-725.

Chauvin, K.W. and Guthrie, J.P. (1994), "Labor Market Reputation and the Value of the Firm", Managerial and Decision Economics, vol. 15, no. 6, pp. 543-552.

Cochran, P.L. and Wood, R.A. (1984), "Corporate Social Responsibility and Financial Performance", The Academy of Management Journal, vol. 27, no. 1, pp. 42-56.

Coffey, B.S. and Fryxell, G.E. (1991), "Institutional ownership of stock and dimensions of corporate social performance: An empirical examination", Journal of Business Ethics, vol. 10, no. 6, pp. 437-444.

Cottrill, M.T. (1990), "Corporate Social Responsibility and the Marketplace", Journal of Business Ethics, vol. 9, no. 9, pp. 723.

De Quevedo-Puente, E., De la Fuente-Sabaté, J.M. and Delgado-García, J.B. (2007), "Corporate social performance and corporate reputation: Two interwoven perspectives", Corporate Reputation Review, vol. 10, no. 1, pp. 60-72.

Dierickx, I. and Cool, K. (1989), "Asset Stock Accumulation and Sustainability of Competitive Advantage", Management Science, vol. 35, no. 12, pp. 1504-1511.

Domench, P.A. (2003), "La divulgación de la información social y medioambiental de la gran empresa española en el período 1994-1998: situación actual y perspectivas", Spanish Journal of Finance and Accounting, vol. 32, no. 117, pp. 571-601. 
Ellen, P.S., Webb, D.J. and Mohr, L.A. (2006), "Building Corporate Associations: Consumer Attributions for Corporate Socially Responsible Programs", Academy of Marketing Science.Journal, vol. 34, no. 2, pp. 147.

Endacott, R.W.J. (2004), "Consumer and CRM: A national and global perspective", The Journal of Consumer Marketing, vol. 21, no. 2/3, pp. 183.

European Commission (2001), Promoting a European framework for corporate social responsibility - Green Paper, Luxembourg: Office for Official Publications of the European Communities.

Fenwick, T. and Bierema, L. (2008), "Corporate social responsibility: issues for human resource development professionals", International Journal of Training and Development, vol. 12, no. 1 , pp. 24-35.

Fernández, J.L. and Luna, L. (2007), "The Creation of Value Through Corporate Reputation", Journal of Business Ethics, vol. 76, no. 3, pp. 335-346.

Fombrun, C.J. (1996), Reputation: Realizing value from the corporate image, Boston: Harvard Business School Press.

Fombrun, C. and Shanley, M. (1990), "What's in a Name? Reputation Building and Corporate Strategy", The Academy of Management Journal, vol. 33, no. 2, pp. 233-258.

Graves, S.B. and Waddock, S.A. (1994), "Institutional Owners and Corporate Social Performance", The Academy of Management Journal, vol. 37, no. 4, pp. pp. 1034-1046.

Griffin, J.J. and Mahon, J.F. (1997), "The corporate social performance and corporate financial performance debate: Twenty-five years of incomparable research", Business \& Society, vol. 36, no. 1, pp. 5-31.

Hall, R. (1992), "The Strategic Analysis of Intangible Resources", Strategic Management Journal, vol. 13, no. 2, pp. 135-144.

Hart, O. (1995), "Corporate governance: some theory and implications", The economic journal, pp. 678-689.

Hoffman, A.J. (1999), "Institutional Evolution and Change: Environmentalism and the U.S. Chemical Industry", The Academy of Management Journal, vol. 42, no. 4, pp. pp. 351-371.

Kim, K. (2007), The Effects of Advertising and Publicity on Corporate Reputation and Sales Revenue: 1985--2005, ProQuest.

Kim, B., Shim, J. and Kim, J. (2001), "Managers' quality and performance perceptions: The case of the Korean semiconductor industry", Total Quality Management, vol. 12, no. 5, pp. 643-655.

Lev, B., Petrovits, C. and Radhakrishnan, S. (2010), "Is doing good good for you? How corporate charitable contributions enhance revenue growth", Strategic Management Journal, vol. 31, no. 2, pp. 182-200.

Lichtenstein, D.R., Drumwright, M.E. and Braig, B.M. (2004), "The Effect of Corporate Social Responsibility on Customer Donations to Corporate-Supported Nonprofits", The Journal of Marketing, vol. 68, no. 4, pp. pp. 16-32.

Lindgreen, A., Swaen, V. and Johnston, W.J. (2009), "Corporate social responsibility: an empirical investigation of US organizations", Journal of Business Ethics, vol. 85, no. 2, pp. 303-323.

Lizcano, J.L. and Moneva, J.M. (2003), Conceptual framework of corporate social responsibility, Accounting, A. E., \& Company, A.

Luo, X. and Bhattacharya, C.B. (2006), "Corporate Social Responsibility, Customer Satisfaction, and Market Value", Journal of Marketing, vol. 70, no. 4, pp. 1-8. 
Mahon, J.F. (2002), "Corporate reputation: A research agenda using strategy and stakeholder literature", Business and Society, vol. 41, no. 4, pp. 415.

Mahoney, L. and Roberts, R.W. (2007), "Corporate social performance, financial performance and institutional ownership in Canadian firms", Accounting Forum, vol. 31, no. 3, pp. 233 253.

Maron, I.Y. (2006), "Toward a Unified Theory of the CSP-CFP Link", Journal of Business Ethics, vol. 67, no. 2, pp. 191.

Martínez, I. and Olmedo, I. (2010), "Theoretical review of reputation in the business environment", Cuadernos de Economía y Dirección de la Empresa, vol. 13, no. 44, pp. 5977.

Moore, G. (2001), "Corporate Social and Financial Performance: An Investigation in the U.K. Supermarket Industry", Journal of Business Ethics, vol. 34, no. 3, pp. 315.

Moura-Leite, R. and Padgett, R. (2014), "The effect of corporate social actions on organizational reputation", Management Research Review, vol. 37, no. 2, pp. 167-185.

Murray, A., Sinclair, D., Power, D. and Gray, R. (2006), "Do financial markets care about social and environmental disclosure?: Further evidence and exploration from the UK", Accounting, Auditing \& Accountability Journal, vol. 19, no. 2, pp. 228-255.

Osterman, P. (1995), "Work/Family Programs and the Employment Relationship", Administrative Science Quarterly, vol. 40, no. 4, pp. 681-700.

Padgett, R.C. and Moura-Leite, R.C. (2012), "The impact of R\&D intensity on corporate reputation: Interaction effect of innovation with high social benefit", Intangible Capital, vol. 8, no. 2, pp. 216-238.

Preston L.E and O'Bannon D.P. (1997), "The corporate social-financial performance relationship", Business and Society, vol. 36, no. 4, pp. 419-429.

Porter, M.E. and Kramer, M.R. (2002), "The competitive advantage of corporate philanthropy", Harvard business review, vol. 80, no. 12, pp. 56-68.

Reese, S.D. and Westphal, J.D. Carroll, C. E. (2004), How the mass media influence perceptions of corporate reputation: Exploring agenda-setting effects within business news coverage, Doctoral dissertation, University of Texas, Austin.

Reverte, C. (2009), "Determinants of Corporate Social Responsibility Disclosure Ratings by Spanish Listed Firms", Journal of Business Ethics, vol. 88, no. 2, pp. 351.

Roberts, P.W. and Dowling, G.R. (2002), "Corporate Reputation and Sustained Superior Financial Performance", Strategic Management Journal, vol. 23, no. 12, pp. 1077-1093.

Roberts, R.W. (1992), "Determinants of Corporate Social Responsibility Disclosure: An Application of Stakeholder Theory", Accounting, Organizations and Society, vol. 17, no. 6, pp. 595.

Saiia, D.H., Carroll, A.B. and Buchholtz, A.K. (2003), "Philanthropy as strategy when corporate charity "begins at home"", Business \& Society, vol. 42, no. 2, pp. 169-201.

Schnietz, K.E. and Epstein, M.J. (2005), "Exploring the Financial Value of a Reputation for Corporate Social Responsibility During a Crisis", Corporate Reputation Review, vol. 7, no. 4, pp. 327-345.

Shapiro, C. (1983), "Premiums for high quality products as returns to reputations", The quarterly journal of economics, vol. 98, no. 4, pp. 659-679.

Sotorrío, L.L. and Diez, E.B. (2011), "Análisis sectorial del efecto de las acciones de responsabilidad social corporativa en la reputación", Revista europea de dirección y economía de la empresa, vol. 20, no. 4, pp. 177-196. 
Theriou, G.N. and Chatzoglou, P.D. (2009), "Exploring the best HRM practices-performance relationship: an empirical approach", Journal of Workplace Learning, vol. 21, no. 8, pp. 614.

Toledano Garrido, N. and Gessa Perera, A. (2009), "Actitud y comportamiento medioambiental de las Pyme: un estudio comparativo", Economía industrial, no. 371, pp. 183-192.

Vilanova, M., Lozano, J. and Arenas, D. (2009), "Exploring the Nature of the Relationship Between CSR and Competitiveness", Journal of Business Ethics, vol. 87, pp. 57.

Vitezić, N. (2011), "Corporate Reputation And Social Responsibility: An Analysis Of Large Companies In Croatia.", International Business \& Economics Research Journal, vol. 10, no. 8 .

Waddock, S.A. and Graves, S.B. (1997), "The Corporate Social Performance-Financial Performance Link", Strategic Management Journal, vol. 18, no. 4, pp. 303-319.

Watson, A., Shrives, P. and Marston, C. (2002), "Voluntary disclosure of accounting ratios in the UK", The British Accounting Review, vol. 34, no. 4, pp. 289-313.

Wilson, R. (1985), "Reputations in games and markets" in Game-theoretic models of bargaining A.E. Roth, New York: Cambridge University Press, pp. 65-84. 
FIGURE 1 Dynamism of building reputation

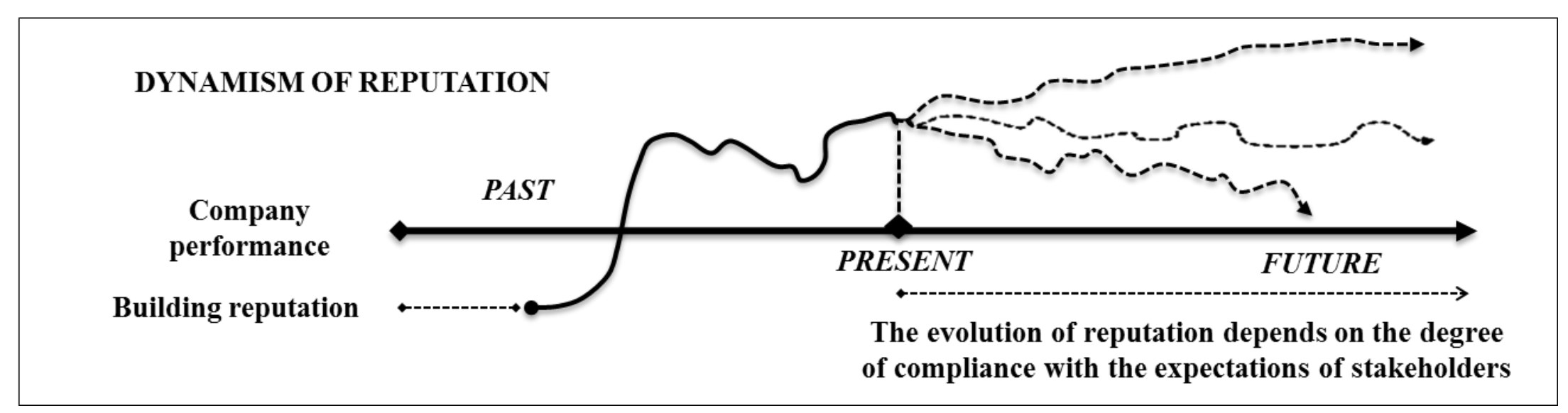


TABLE 1 Areas of interest and items considered for the construction of the LSR index.

\begin{tabular}{l} 
Areas of interest of LSR \\
\hline EMPLOYMENT TRANSPARENCY - Company information in \\
order to increase transparency about their employment figures
\end{tabular}

LABOUR / MANAGEMENT RELATIONS - In the context of HR management several aspects that can improve labour relations are considered, such as: Reconciling family and professional life; outplacement service and studies of satisfaction.
Does the company disclose information about this items?

Yes (1) / No (0)

L1. Number of employees and breakdown by categories

L2. Information regarding staff membership to unions

L3. Labour practices (parental leave, flexible hours, extended

leave of absence...)

L4. Programs or policies to balance work and family life

L5. Existence of outplacement services for employees

L6. Studies of employee satisfaction or work environment

OCCUPATIONAL HEALTH AND SAFETY - Safety in the workplace

L7. Health and safety conditions at work

TRAINING AND EDUCATION - This section clarifies that the company invests in lifelong learning of its employees

L8. Training programs for employees and career development

DIVERSITY AND EQUAL OPPORTUNITY - Greater diversity of human resources, equal pay and career prospects for women and disabled people

L9. Distribution of employees by gender

L10. Information about disabled people in the workforce

L11. Remuneration and compensation policies of the company

PARTICIPATION AND DELEGATION - Workers take more implication in their firm because of their participation in profits or shares of the company

L12. Employee participation in company-owned

L13. Employee participation in company profits

* METHODOLOGICAL NOTE: The information for coding of each item will be obtained from the disclosure of information available to stakeholders on the LSR actions of the company. For example, if the company disseminates information on the number of employees and breakdown by category (full-time or part-time, temporary or permanent contract ...) the $\mathrm{L} 1$ item receives the value 1 and 0 otherwise. Once checked all items the mean value of the scores is calculated $((n 1+n 2+\ldots \ldots .+n j) / 13)$, and as a result it is obtained a score between 0 and 1 for LSR index of each firm. This index is an approximation of socially responsible labour actions carried out by the company according to the information disclosed to its stakeholders. 
TABLE 2 Descriptive statistics

\begin{tabular}{|c|c|c|c|c|}
\hline \multicolumn{5}{|l|}{ Corporate Reputation sample $(N=477)$} \\
\hline Variables & Mean & $S D$ & Maximum & Minimum \\
\hline \multicolumn{5}{|l|}{ Dependent variable } \\
\hline CR & $3,653.12$ & $1,762.58$ & 10,000 & 1178 \\
\hline \multicolumn{5}{|l|}{ Independent variable } \\
\hline LSR & 0.37 & 0.27 & 0.92 & 0.00 \\
\hline \multicolumn{5}{|l|}{ Control variables } \\
\hline SIZE (thousands of $€$ ) & $2.96 \mathrm{e}+07$ & $1.21 \mathrm{e}+08$ & $1.22 \mathrm{e}+09$ & 259.86 \\
\hline FINALCIAL PERFORMANCE (\%) & 23.86 & 67.13 & 474.14 & -748.78 \\
\hline INDEBENESS (\%) & 64.87 & 25.02 & 135.75 & 2.86 \\
\hline VISIBILITY & 0.64 & 0.48 & 1 & 0 \\
\hline ENVIROMENTAL IMPACT & 0.23 & 0.42 & 1 & 0 \\
\hline \multicolumn{5}{|l|}{ Labour Reputation sample $(N=461)$} \\
\hline Variables & Mean & $S D$ & Maximum & Minimum \\
\hline \multicolumn{5}{|l|}{ Dependent variable } \\
\hline LR & $3,483.81$ & $2,067.25$ & 10,000 & 404 \\
\hline \multicolumn{5}{|l|}{ Independent variable } \\
\hline LSR & 0.37 & 0.27 & 0.92 & 0.00 \\
\hline \multicolumn{5}{|l|}{ Control variables } \\
\hline SIZE (thousands of $€$ ) & $3.00 \mathrm{e}+07$ & $1.24 \mathrm{e}+08$ & $1.22 \mathrm{e}+09$ & 259.86 \\
\hline FINANCIAL PERFORMANCE (\%) & 24.51 & 68.39 & 474.14 & -748.78 \\
\hline DEBT $(\%)$ & 64.86 & 24.93 & 135.75 & 2.86 \\
\hline VISIBILITY & 0.59 & 0.49 & 1 & 0 \\
\hline ENVIROMENTAL IMPACT & 0.24 & 0.43 & 1 & 0 \\
\hline
\end{tabular}

TABLE 3 Pearson Correlation matrix

\begin{tabular}{|c|c|c|c|c|c|c|c|}
\hline \multirow[b]{2}{*}{ Variables } & \multicolumn{7}{|c|}{ Corporate Reputation sample } \\
\hline & $C R$ & $L S R$ & SIZE & FP & Debt & Visib & Envi \\
\hline \multicolumn{8}{|l|}{$C R$} \\
\hline$L S R$ & $.287^{* * * *}$ & & & & & & \\
\hline SIZE & $.433^{* * *}$ & $.197^{* * *}$ & & & & & \\
\hline$F P$ & -.019 & -.003 & -.022 & & & & \\
\hline$D E B T$ & -.018 & .030 & $.227^{* * * *}$ & $-.090^{* *}$ & & & \\
\hline VISIB & $.177^{* * *}$ & .030 & $.161^{* * * *}$ & -.053 & .068 & & \\
\hline \multirow[t]{2}{*}{$E N V I$} & .023 & $.265^{* * *}$ & $-.096^{* *}$ & -.015 & $-.165^{* * * *}$ & $-.147^{* *}$ & \\
\hline & \multicolumn{7}{|c|}{ Labour Reputation sample } \\
\hline Variables & $L R$ & $L S R$ & SIZE & $F P$ & Debt & Visib & Envi \\
\hline$L R$ & & & & & & & \\
\hline$L S R$ & $.189^{* * *}$ & & & & & & \\
\hline SIZE & $.403^{* * * *}$ & $.165^{* * * *}$ & & & & & \\
\hline$F P$ & -.038 & -.006 & -.023 & & & & \\
\hline$D E B T$ & .005 & .012 & $.225^{* * * *}$ & $-.087^{*}$ & & & \\
\hline VISIB & $.306^{* * * *}$ & -.033 & $-.177^{* * * *}$ & -.053 & .021 & & \\
\hline ENVI & $-.112^{* *}$ & $.261^{* * *}$ & $-.098^{* *}$ & -.019 & $-.166^{* * *}$ & $-.147^{* *}$ & \\
\hline
\end{tabular}

Significance levels: $* * *$ indicates significance at $99 \%, * *$ indicates significance at $95 \%$, $*$ indicates significance at $90 \%$. 
TABLE 4 System GMM Estimates of corporate reputation and labour reputation.

\begin{tabular}{|c|c|c|c|c|c|}
\hline \multicolumn{3}{|c|}{ Dependent variable: Corporate Reputation (CR) } & \multicolumn{3}{|c|}{ Dependent variable: Labour Reputation (LR) } \\
\hline $\begin{array}{l}\text { Independent } \\
\text { variables }\end{array}$ & $\begin{array}{l}\text { Standardized } \\
\text { coefficient }(\boldsymbol{\beta})\end{array}$ & Signif ${ }^{1}$ & $\begin{array}{l}\text { Independent } \\
\text { variables }\end{array}$ & $\begin{array}{l}\text { Standardized } \\
\text { coefficient }(\boldsymbol{\beta})\end{array}$ & Signif ${ }^{1}$ \\
\hline$C R t-1$ & 0.8388 & $* * *$ & $L R t-1$ & 0.7764 & $* * *$ \\
\hline LSR & 0.0944 & $* * *$ & LSR & 0.0768 & $* * *$ \\
\hline SIZE & 0.0925 & $* * *$ & SIZE & 0.1234 & $* * *$ \\
\hline FP & -.0 .0015 & - & FP & 0.0143 & - \\
\hline INDEB & -0.0540 & $* *$ & INDEB & -0.0570 & $* * *$ \\
\hline VISIB & 0.0422 & $* * *$ & VISIB & 0.0573 & $* * *$ \\
\hline ENVI & -0.0279 & $* *$ & ENVI & -0.0250 & $* *$ \\
\hline Constant & 0.0758 & $* * *$ & Constant & -0.3418 & $* * *$ \\
\hline Specification test & Statistic & P-value & Specification test & Statistic & P-value \\
\hline Arellano-Bond Test M1 & -3.25 & $(0.001)$ & Arellano-Bond Test MI & -5.23 & $(0.000)$ \\
\hline Arellano-Bond Test M2 & 0.23 & $(0.815)$ & Arellano-Bond Test M2 & 1.67 & $(0.095)$ \\
\hline Hansen test & 65.22 & $(0.213)$ & Hansen test & 57.52 & $(0.530)$ \\
\hline $\begin{array}{l}\text { Wald Test for the } \\
\text { explanatory variables }(z 1)\end{array}$ & $\begin{array}{l}\mathrm{F}(7,101)= \\
5301.68\end{array}$ & $\begin{array}{l}\text { Prob }>F \\
0.000\end{array}$ & $\begin{array}{l}\text { Wald Test for the } \\
\text { explanatory variables }(z 1)\end{array}$ & $\begin{array}{l}\mathrm{F}(5,68)= \\
29068.21\end{array}$ & $\begin{array}{l}\text { Prob >F } \\
0.000\end{array}$ \\
\hline $\begin{array}{l}\text { Wald Test for the time } \\
\text { dummy variables }(z 2)\end{array}$ & $\begin{array}{l}\mathrm{F}(3,101)= \\
65.35\end{array}$ & $\begin{array}{l}\text { Prob }>F \\
0.000\end{array}$ & $\begin{array}{l}\text { Wald Test for the time } \\
\text { dummy variables }(z 2)\end{array}$ & $\begin{array}{l}F(2,68)= \\
472.72\end{array}$ & $\begin{array}{l}\text { Prob }>\mathrm{F} \\
0.000\end{array}$ \\
\hline
\end{tabular}

${ }^{1}$ Significance levels: $* * *$ indicates significance at $99 \%$, ** indicates significance at $95 \%$, * indicates significance at $90 \%$. The dummies were included in the analysis but not included in the table. 